\title{
SPEAKING THE LANGUAGE OF THE KINGDOM OF GOD IN THE CONTEXT OF A SOCIETY IN TRANSITION
}

Author:

Friedrich W. (Fritz) de Wet ${ }^{1}$

\section{Affiliation:}

${ }^{1}$ School for Ecclesiastical

Sciences, North-West

University, Potchefstroom

campus, South Africa

\section{Correspondence to: \\ Fritz de Wet}

email:

fritz.dewet@nwu.ac.za

\section{Postal address:}

School for Ecclesiastical

Sciences, PO Box 20004,

Noordbrug 2522,

South Africa

\section{Keywords:}

biblical covenant; kingdom

of God; performative

language; revelational

theme; society in

transition; South Africa;

speech act theory

\section{Dates:}

Received: 05 Nov. 2009

Accepted: 12 Mar. 2010

Published: 13 July 2010

How to cite this article:

De Wet, F.W., 2010,

'Speaking the language

of the kingdom of God in

the context of a society in

transition', HTS Teologiese

Studies/Theological Studies

66(1), Art. \#732, 7 pages.

DOI: $10.4102 /$ hts.v66i1.732

This article is available

at:

http://www.hts.org.za

(C) 2010. The Authors. Licensee: OpenJournals Publishing. This work is licensed under the Creative Commons Attribution License.

\section{ABSTRACT}

Venturing to speak the biblical language of the kingdom of God, with its distinct covenantal intensity, in the context of a South African society in transition from paternalistic power structures to liberal democratic structures is not easy. How should the language of the kingdom of God be spoken in a society that demands 'non-intrusive' and 'politically correct' speech without - in the process - rendering the intense intentionality of its covenantal roots to that of a speech without zeal? Having to face the daunting task of 'translating' kingdom language into a type of language that suits the present-day context without sacrificing or diminishing its powerful intentionality demands the development of a new sensitivity. Such a sensitivity is required to incentivise the accommodation of the dimensions of truthful, authoritative and authentic communication in spoken language. In this research article, the implications of the speech act theory, as pioneered by scholars such as J.L. Austin and J. Searle, are utilised to identify possible markers for such a venture. Insight into the locutionary, illocutionary and perlocutionary dimensions present in speech acts is indicated as a relevant starting point for attempting to obtain a more comprehensive and perspective-rich understanding into speaking the language of the kingdom of God in a way that fits the present South African context.

\section{INTRODUCTION}

The development of a theory regarding the speaking of the boundary-shattering, authoritative and living language of the kingdom of God in the context of a society in transition presents theological language (especially with respect to its communicative intent) with unique challenges. South African society finds itself in a dualistic transition from, (1) paternalistic power structures of the colonial age, with their authoritarian and biased language, to liberal democratic structures, with the voice of the people as its polyphonic language and (2) from the foundationalist structure of modernism with its positivistic language of set and sure, integrated, objective truths, to the fragmentism of postmodern culture, with its language of endless, contextual possibilities, internalised constructions and consumerist transience (Vorster 2007:vii; cf. Chan 2007:311; Loscalzo 2000:84).

Nouwen (1972) clearly expresses the predicament faced when trying to communicate the Christian message to people in a changing, secular and fragmented world. It can no longer be assumed that such people have a natural frame of reference to an all-encompassing and plan-like pattern of divine presence in terms of their own reality. Nouwen (1972) states:

When we wonder why the language of traditional Christianity has lost its liberating power for nuclear man, we have to realize that most Christian preaching is still based on the presupposition that man sees himself as meaningfully integrated with a history in which God came to us in the past, is living under us in the present, and will come to liberate us in the future. But when man's historical consciousness is broken, the whole Christian message seems like a lecture about great pioneers to a boy on an acid trip.

(Nouwen 1972:9)

Communicating the language of the kingdom of God in such a context is further complicated by the growing suspicion of the idea of a metanarrative that encompasses the grand master plan, which gives meaning and resolution to those issues relating to human existence. Such a metanarrative has its classic expression in the Augustinian pattern of Creation, falling in sin, salvation and, ultimately, consummation (cf. Boeve 2004:307). Johnston (2001:107) states that, in the context of postmodernism, a state that is marked by the absence of life-giving answers would seem to be preferable to one that is marked by an oppressive ideology. According to such an outlook, living in despair is preferable to being fooled into accepting a lie that seeks ultimately to enslave others for self-serving purposes. In other words, it is better to be hopeless than to be foolish. The incredulity of the metanarrative is a symptom of the cynicism of our times. When Christianity is reduced to the status of an all-encompassing ideology, 'nuclear man' is all too prone to be sceptical about the relevance of such a religion to his or her own life experience (Nouwen 1972:12; Root 2007:560). Language that 'pressurises' people into becoming convinced of their own sinfulness and the need to commit their life to the only One who can bring salvation and consummation is likely to be seen as a form of subtle manipulation that is capable of enslaving people to the self-serving purposes of the church and its agenda.

To communicate the presence of the King, as well as the vision and the praxis of the kingdom in authoritarian, slotted, closed and impersonal language might discourage Christians from authentically connecting with their kingdom identity and destiny. Christians increasingly find themselves in a complex, flexible and largely disillusioned society, which is dominated by a search for instant gratification. However, in contrast, if bound by the need to use 'safe', 'non-intrusive' language, those words that are used to convey the message of the church may become meaningless and superficial.

'Translating' the kingdom language into the current context without sacrificing or diminishing the power and importance of its intentionality demands that a new sensitivity be developed to the nuances 
of truthful, authoritative and authentic communication that are present in the spoken word. In this research article, the biblical concept of the kingdom of God will be briefly explored in relation to its roots and structure, with the intent to focus on the particular language proceeding from the structure. Theories regarding the different dimensions of language (specifically those of Austin and Searle regarding speech acts) will be used, on a theological level, to theorise about the responsible and effective communication of God's kingdom by means of contemporary language acts. Taking the different dimensions of language into account, theological theory should ask in which sense the full spectrum of language can be utilised in speaking the language of the kingdom of God truthfully, authoritatively and authentically.

\section{LANGUAGE OF THE KINGDOM OF GOD}

In researching the language of the kingdom of God, it will be necessary briefly to explore the biblical concept of the kingdom of God in relation to its roots and its structure. By means of such an exploration, it should eventually be possible to gain an effective awareness and understanding of the particular language proceeding from this concept.

Based on a comparative reading of biblical literature, this study uses, as its point of departure, the fact that the Bible has a revelational unity that transcends its overall diversity. God's contact with this world and his redemptive relationship with his people are frequently expressed in kingdom terminology. The subject matter of 'biblical theology' is, in fact, God's relationship with his people throughout salvation history, as is recounted in scripture (Hafemann 2007:20). The concept of the kingdom of God is widely regarded as one of the central issues of biblical revelation (Bright 1962:7; Rottenberg 1980:11; Vorster 2007:252). In essence, the kingdom is about the reign of God. The Old Testament proclaims the reality of the rule of God over the whole of creation, as well as over the destiny of nations. The New Testament proclaims the rule of God as it becomes manifest in the coming of Christ and the formation of the people of God (Vorster 2007:252). From the start of his ministry, Jesus understood that an appreciation of the drawing near of the kingdom of heaven was key to understanding his mission (Mt 4:17). The kingdom is associated with good news (Mt 4:23), as, when the kingdom draws near, all powers and authority that have a detrimental, enslaving effect on life can be seen to be overpowered and broken. In terms of such an understanding, those bowing before Jesus Christ and accepting him as king through faith become liberated from sin and death, finding themselves in a sphere in which the heavenly blessings of eternal life open up for them. The New Testament description of the kingdom of God as the coming of 'the age to come' into this 'present evil age' (Lk 18:30; Gl 1:4) and the ushering in of the contrast between life 'in the flesh' and the 'new life of Spirit' (Rm 7:5-6; 8:5-9) is not a description of an other-worldly reality confined to the realm of the spiritual; on the contrary, the kingdom of God is about redeeming and transforming the present world (Chan 2007:316; Rottenberg 1980:17).

Church-related activities are portrayed as being concerned with kingdom activity: the church is, at its heart, a kingdom community, presenting itself as a royal priesthood in proclaiming the good news of the kingdom, ministering the riches of the kingdom and waiting like a bride for the return of the King, at which time his kingdom will be consummated (1 Pt 2:9; Rv 22:17; Hendriks 1991:132).

Huat Tan (2005:150) links the concept of the kingdom of God and the nature of the relationship between the King and his adherents with the covenant concept, as it initially functions in the Old Testament. Jesus's death must be understood within the broader story of gracious covenant-making. The story includes the breaching of the covenant, in response to which Yahweh reaches out to Israel to bring about a definite covenantal relationship that cannot be breached. At the climax of the story, the love of Yahweh is demonstrated by means of the sacrifice of Jesus in the inauguration of the covenant, as well as by the bringing about of the restoration of Israel. Hafemann (2007:23) regards the covenant as the interpretive lens through which the conceptual and historical unity of the Bible, amid its diversity, can clearly be seen.

The notion that, at the climax of the covenant, Yahweh will act powerfully, both to vindicate himself and to rescue his people, is frequently described by the prophets, though such powerful action is most clearly evidenced in Deutero-Isaiah. The declaration of God's reign is tied up with the return of his people from exile and their participation as beneficiaries of a ceremony that serves to ratify the covenant. Such a covenant is understood as being eternal (i.e. unbreakable) and as issuing in salvific conditions for those who are restored (Is 59:15b-21; 61:4-9). Yahweh's return to reign in Jerusalem may, therefore, be construed as the eschatological phase of the covenantal relationship between Yahweh and his people (Huat Tan 2005:126).

The roots of the kingdom in the covenantal relationship between God and his people are important. The covenantal relationship is, according to Huat Tan (2005:125), above all, relational. Those in covenantal relationship with God are regarded as his people. The covenant is not merely about rules and regulations, as its existence presupposes a relationship constitutive of identity. In short, the very concept of the covenant itself entails reference to a distinctive people. At the heart of the covenantal relationship lies the concept of mutual agreement and solemn commitment (Dumbrell 1984:19; McComiskey 1985:228). Bunting (2005:202) indicates that the covenantal treaties of the Near East, to which the biblical descriptions of the covenant between God and his people allude, are bilateral rather than unilateral, in that both parties to such treaties assume responsibilities and form expectations of certain associated benefits. Although God's covenantal relationship with his people is monopleuric in its origin, it is clearly dupleuric in its functioning (Vorster 2007:195). Being surprised and overjoyed by the overflowing goodness of God's total commitment and his unreserved forgiveness of sins through the climatic act of the sacrifice of Christ, the most fitting ways in which the human covenantal partner can react is by entering God's presence with a sincere heart and ministering the goodness of God with total commitment (Burns 2009:158-177).

From the analysis of biblical language used to describe the nature of the relationship between God and his people, a pattern of distinct intensity emerges:

- God reveals himself as Yahweh echad (Dt 6:4). He loves his people with a burning, undivided intensity. Such unconditional love can only be answered with all the heart, all the soul and all the strength (Dt 6:5). There is no place for half-heartedness in the covenantal relationship with God.

- Neither breaking such a covenant, nor the possibility of leading a fulfilled life outside the covenant, is conceivable. Breaking the covenant with the living God would result in being cut off from the very source of life. Such an action could only result in a cursed life that withers away in fruitlessness and becomes corrupted unto death. To express the inconceivability of leading such a cursed life, language is used that expresses the zeal, compassion and righteousness with which the holiness of life in the covenantal relationship is protected. Such language clearly states that all covenantbreaking and marginalising factors will be brought to their due end. In giving his holy law to the covenant community, Yahweh (who reveals himself in this way as One who, in his flaming righteousness and love, is simultaneously both deus absconditus and deus absolutes) refers to himself as a jealous God. He is capable of punishing children for those sins that were committed by their fathers to the third and fourth generation of those who hate him. In contrast, he is also capable of showing love to a thousand generations of those who love him and who keep his commandments (Ex 20:5-6). 
- To express the abundance of God's compassion, grace and love for his people, as well as the joy and amazement that such generosity generates in the hearts of covenant people requires the use of a specific type of language, as does the utter dismay and alarm that is experienced in response to any thought of breaking the covenant. To express such emotion, poetic language is often used, such as that used to speak of a husband's unabating love for his wife (Is 54:4-8), or that which is used to express long-suffering paternal love (Ps 103:8, 13).

The same level of covenantal intensity also emerges from the kingdom of God language used, especially as such use is to be found in the New Testament. Such a fire burns in the heart of Jesus Christ that it consumes him with love for the house of his Father (Jn 2:16-17). His only desire is to do the will of his heavenly Father with his whole being. He is said to be filled with heartfelt compassion for harassed and helpless people (Mt 10:36), resulting in him, in a fit of inspired rage, upturning the tables of those people who sought to pervert the house of his Father into a den of robbers. In response to his utmost love for his disciples (Jn 13:1), his followers should express a righteousness greater than that of the Pharisees, reflecting nothing less than the holiness of their heavenly Father (1 Pt 1:16) and expressing unconditional, self-sacrificing commitment to the following of Jesus (Mt 10:39; Rottenberg 1980:17). To lead a life not completely devoted to God is inconceivable: 'Neither the sexually immoral nor idolaters nor adulterers nor male prostitutes nor homosexual offenders nor thieves nor greedy nor drunkards nor slanderers nor swindlers will inherit the kingdom of God' (1 Cor 6:9-10).

The intensity of the covenant language underlying the kingdom of God rhetoric can lead, when superficially heard or irresponsibly employed, to criticism and scorn of the limited and particular nature' of the covenant promises, the 'exclusive nature' of the associated blessings and the 'dark and terrible punishments' promised to those who would break, as well as by those who have broken the covenant, or who have not been included in the covenantal relationship (Bunting 2005:202).

The intensity of kingdom language can certainly be conveyed irresponsibly in the current context if it is accompanied by a Bible-thumping force or uttered in a threatening tone. So-called 'fire and brimstone' sermons can easily be associated with the use of that type of language that is employed in an attempt to manipulate people by placing undue pressure on them. The kingdom of God is not a case of rule by fear, but is rather a case of being willingly filled with the Spirit of sonship ( $\mathrm{Rm} 8: 15)$. In the kingdom of God, neither a manipulative power structure exists, nor is there enforcement of allegiance by means of the issuance of threats. Loscalzo (2000) recalls being in the company of evangelists and apologists who, despite constantly being prepared to account for the hope that they had (with reference to $1 \mathrm{Pt}$ 3:15), wielded such accounts like a weapon:

We sometimes joke about evangelists beating people over the head with the Bible to win their allegiance. While the Gospel itself may be an intrusive word, there is no need for those of us who preach to be personally offensive. Gentleness and reverence exemplify the stance we should take when we preach. The gospel demands no less, and Jesus himself will demand no more.

(Loscalzo 2000:92)

Loscalzo (2000) encourages the responsible use of kingdom language in the current context by referring to the communicative style that Jesus used in bringing the message of the kingdom of God to God's people. Rather than entering into an argument with those who disagreed with him, Jesus often responded with questions, or with a pointed anecdote. Instead of lashing out in anger or ridicule, he spoke with gentleness and reverence.

However, his use of gentleness and reverence does not imply that the intensity of the covenantal roots should be reduced and rendered without zeal in the current context, which demands the use of civilised and 'politically correct' speech. Gentleness and a sense of reverence do not simply imply mildness, but also encompass feelings of sensitivity to others, as well as the ability to be finely attuned to all that is true, right, pure, lovely, admirable and excellent (Phlp 4:8). To portray a gentle, meek and mild 'New Testament God' who - unlike the 'Old Testament God' - is not filled with a sense of burning righteousness against all those distorting elements that are capable of corrupting the holiness of the covenantal relationship with his people, is to distort the underlying principles of kingdom language.

The answer to presenting the Gospel in an authentic way (by communicating the language of the kingdom of God in a responsible way within the current context) is, in my view, not found in adjusting or decreasing the underlying covenantal intensity, but rather in carefully aligning all the dimensions of language communication according to the intensity of the covenantal language used. When only the denotative meaning of language is communicated in a dogmatically sound way and intent (of a Father who wishes the best for his children and who will tolerate nothing that might make them unhappy) is divorced from expression, the words can appear sterile and lifeless, coming to be interpreted as manipulative and exclusivist. Finding some insight into the different dimensions that are present in verbal and written communication is, therefore, necessary. In the following section of this article, speech act theory will be investigated, with specific reference to its implications for the responsible and effective communication of the language of the kingdom of God.

\section{SPEECH ACT THEORY}

When reasoning about the function of language in interpersonal communication, it seems obvious that language cannot be viewed as merely a combination of words. Communication by means of language does not take place in a vacuum. The concept of 'language', when viewed together with its effects from the vantage point of the speaker, not only refers to the words spoken in terms of their symbolic character, but also to the reason behind, or motivation for, speaking, as well as to the way in which they express the speaker's relationship with the listeners concerned, including his or her relationship to the matters discussed. Activity can, therefore, be seen to take place at a number of different levels when a speaker says something (cf. Dingemans 1991:168). In the field of language philosophy, the so-called speech act theory was pioneered by such scholars as J.L. Austin (in his text How to do things with words, first published in 1962) and J.R. Searle (in the text Speech acts: An essay in the philosophy of language, produced in 1969). Speech act theory is a theory of language use and its effects. In his work, Austin looked at the effects of different kinds of utterances in conversation and other speech, meaning the performative aspect of language usage. The words 'It is cold today', when addressed to a person entering a room might, for example, prompt the person concerned to close the door. The words ' $I$ do' $^{\prime}$, when spoken in the specific context of the marriage ceremony, can establish a legally binding contract between two people (Botha 2007:275; Mann 2009:316). Speech act theory primarily concerns itself with the performative nature of language, with the operation of language 'utterances', which produce certain effects, no matter whether they occur in faceto-face personal conversation or in any communicative action (Briggs 2001:3). Speech act theory should not be viewed as a comprehensive theory of language that can be used in isolation from other theoretical considerations and that is needed for understanding the various dynamics of the spoken word. Rather, such theory underpins an awareness of the effects of the use of certain utterances in specific speech situations (Botha 2007:276).

In terms of speech act theory, the following action structures should be distinguished in speech:

- Underlying speech and the acts flowing from it, is the propositional element (with a referral and predicative function), which encompasses the information to be 
communicated. Such a locutionary act presents itself at the level of 'saying something'. According to its propositional dimension (or meaning), a speech act can be either truthful or untruthful.

- The intent of the speaker in the language act concerned is communicated in the form of an intentional act. The act of speech is given an illocutionary force, by means of which the speaker intends to persuade the listeners to act in a certain way by presenting language as a command, or as an appeal or a question. The illocutionary act involves the performance of an act in saying something as opposed to the performance of an act of saying something. According to its illocutionary dimension (its intent), a speech act can be either justified or unjustified.

- At the relational level of speech acts, the speaker's relationship with that to which is referred, on the one hand, and with the listeners, on the other, is expressed. At such a level, the element of persuasion is also present. Saying something usually affects the feelings, thoughts, or actions of the audience, the speaker, or other persons. An act of speech which is (possibly intentionally) performed in this way is termed a perlocutionary act. When communication at this level is received as authentic, its effect can be convincing. According to its perlocutionary dimension (referring to the expression), a speech act can be either authentic or fabricated (Austin 1962; Botha 2007:277-278; Briggs 2001:41; Dörge 2004:48-55; Searle 1969; Wolterstorff 1995:37).

Vanhoozer (1998:457) uses the basic action structures identified by speech act theory to develop his view on the function of language in Trinitarian theology. By acting as a transcendental agent, the Trinity satisfies a necessary condition for the possibility of something that humans experience but which they cannot otherwise explain, namely the experience of meaningful communication. God's very being is a self-communicative act, which both constitutes and enacts the covenant of discourse, in the form of the interrelationship between the speaker (the Father), the Word (the Son) and the reception (the Spirit). If the Father is the locator, the Son is his preeminent illocution. Christ is God's definitive Word, being the substantive content of his message. The Holy Spirit, which serves as the condition and power of receiving the sender's message, is God as the perlocutor, providing the reason for his words not returning to him devoid of meaning (Is 55:11). The triune God is, therefore, the epitome of communicative agency, serving as the speech agent who utters, embodies and keeps his Word. Human speakers, who are created in God's image, enjoy the dignity of communicative agency and experience communication as a covenantal affair, though, as sinners, their speech acts (and interpretations) are subject to all imperfections and distortions that characterise the state of human fallenness.

Vanhoozer's perspective on the Trinitarian pattern, which is echoed in human speech acts, is significant in anchoring theological theory in language acts, within the context of God's kingdom. From a theological point of view, the acts involved in human communication have always been studied with respect to the extent to which, or the manner in which, they reflect God's meaning and intent. Such acts represent the expression of the unbroken, fulfilling communion with God. Those who see themselves as being in God's service and tasked with proclaiming the Gospel of the kingdom of God, will always try to relate what they say and do with what God says and does. When speech is intended to reveal the full implications of the kingdom of God, the words chosen for such revelation should resemble God's own words (1 $\mathrm{Pt} 4: 11)$. In terms of the traditional theology of the Reformation, such a connection is made manifest in the use of the phrase Sola Scriptura. In such words, the speaker places himself or herself under the guidance of the Spirit, who knows and reveals the hidden things of God. Such a speaker always uses the Word of God, as it appears in the Holy Scriptures, as the text which fully determines the way in which he or she chooses to speak, and in which he or she gains confidence in speaking, about God. In other words, the speaker does not want to add anything to, or to take anything away from, God's Word in conveying it to the audience concerned.

Dingemans (1991:168) comments on the value of speech act theory from a theological standpoint on the function of language by showing how a practical theological discipline, such as homiletics, traditionally only considered the semantics of language. The adoption of such an approach entailed an attempt to formulate the meaning of the biblical text in such a way that the message concerned should be expressed as clearly as possible. According to Dingemans, the speakers of the Word of God should realise that the biblical text is not only meaningful, but also has an evocative power and a relationship-determining effect. By means of the evocative power which is present in the biblical text, those who access such text are urged to believe, while simultaneously being confronted with the inconceivability of not believing. In responding to the language of such text, both speaker and listener are filled with a sense of childlike trust, wonder, awe and joy, as they become increasingly aware of how rewarding it is to have an ongoing relationship with the God who reveals himself through his Word.

The vantage point that is gained by way of speech act theory has profound implications for the development of theological theory. Such theory opens up new options for addressing those problems which have traditionally been associated with speaking the language of the kingdom. The latter context allowed solely for the holding of a one-dimensional view on the function and impact of language, which meant that the language of the kingdom of God was expressed and experienced as manipulative, exclusionary, irrelevant and inauthentic. The possibilities that are made available through the adoption of an approach that is based on speech act theory are explored in the next section.

\section{DEVELOPING A THEOLOGICAL THEORY}

\section{Contexualising the language}

I will now discuss the development of a theological theory on which to base the speaking of the language of the kingdom in the current context of a society in transition. In the above theological reflection on the implications of speech act theory, two perspectives emerged, that, to my mind, are very important for theorising about speaking the language of the kingdom of God in the current context of a South African society in transition. The society is adapting to the implications of secularism, postcolonial politics and postmodernity. The two perspectives consist of the following:

Firstly, in developing theological theory, the reasoning should be anchored in the full and living structure of language, as it is ultimately embodied as covenantal discourse in the Trinitarian communion. In the acts of the speech agent who utters, embodies and keeps his Word, there can be no communicative distortion or incompleteness. The Triune God is in no way at odds with his Word. In no way is his Word rendered powerless by a speech act that deceives in telling half-truths or in uttering statements that later prove to be misleading. In no way can his Word be rendered unjustifiable due to its placing improper pressure on, or manipulating, the listener. In no way can his Word be rendered inauthentic by the disillusioning experience of a listener who sees a different reality to that to which his expectations are raised by means of the spoken word. He does not remain true to his Word only up to a certain point. The speaking of a language that is truthful, authoritative and authentic proceeds on the basis of a personal communion with the living God, who reveals himself as the Triune of the Father, the Son and the Holy Spirit.

Secondly, in listening to the language of the kingdom of God, as it is written and expressed in the biblical text, a theory should be developed for speaking such language. Such language consists of a comprehensive speech act, which is sensitive to the full impact 
of the clear meaning, the earnest intent and the expression of dedicated involvement, which are to be found in the language structure of the text.

\section{The locutionary speech act}

Contrasting the unimaginably vast truth of the coming of the kingdom of God with the oversimplified, absolutistic truth: As has already been stated, the rejection of the concept of an overarching metanarrative seems to be one of the key symptoms of the spirit of cynicism that seems to prevail in our heterogeneous times. A truth that is communicated to people in a set, unchanging form is easily met with the suspicion that they are being encouraged to think in a certain way so as to conform to a 'hidden agenda', which is adhered to by those trying to maintain the power structures of the privileged (Allen 2001:38; Chan 2007:309). In postmodernism, 'truth' is constructed, not discovered (Groothuis 2004:441). The type of language that is enacted in terms of set formulae might also be experienced as a type of language that is used to attempt to explain complex issues in an oversimplified way. The challenge posed to a language that endeavours to explain the metanarrative of the kingdom of God in a clear, unambiguous way can no longer be met by simply formulating truths in closed, dogmatic terms (Pieterse 2005:420; Vos 1996:271). Such a metanarrative consists of the basic anchors that believers need from Scripture in order to grow in their knowledge of God. They need to anchor their lives on the kingdom of God at its source, as well as in the current presence of the kingdom and in the anticipation of the eschatological consummation of a kingdom-directed life.

Brueggemann (1997) describes the chain of events that can be initiated when kingdom language is spoken in a set, formulaic way:

All but the most closed and sheltered liturgic congregations are indomitably heterogeneous. That emerging pluralism, moreover, cannot any longer be overcome by absolute assertion. For such absolute assertion, whether by strong pastoral authority or by denominational dictum, can only serve to excommunicate those who see and take experience otherwise. The more frantic our zeal to maintain the oneness and wholeness of 'our truth', the more divisive such practice becomes.

(Brueggemann 1997:25)

Attempting to control the truth is an inadequate coping mechanism for a situation characterised by diversity. In the same vein, the alternative to oversimplification, cliché and absolutism does not lie in over-complicating the language used, to the extent that it loses its clarity. Wherever the kingdom of God is present, light shines clearly and darkness is driven away (1 Jn 1:5). Speaking kingdom language should never leave the listener in the dark, or in a state of mind in which the shadows of doubt remain, resulting in a half-hearted response to the Word.

The answer to the problem of speaking kingdom language in such a way that those who have been given eyes will start to see the clear meaning and the full extent of what the kingdom entails, to my mind, starts with what Johnston (2001) says:

Due to the cold analysis of modernity and the subjective fragmentation of postmodernity, the largeness of our God remains an on-going theological theme for twenty-first century listeners. That means biblical communicators must learn to speak about God in more than sound bites and superficial jargon.

(Johnston 2001:114)

An overjoyed sense of amazement over the vastness of God's goodness as manifested in his kingdom, rather than an absolutist sense to control, should fill the heart and mind of the speaker (cf. Müller 1996:67). The heart of clarity then lies in being overwhelmed; akin to the experience of looking through the repaired Hubble telescope for the first time and being overwhelmed by the overabundance of the starry heaven in all its glorious, unsearchable clarity. Although the perceiver lives in a broken world, in which clear-cut answers cannot be readily given for the complexities of this transient life, crystal clear kingdom light is breaking into this reality. The truthfulness, glory and goodness of this light fill the perceiver with an inward groaning for the consummation of this kingdom ( $\mathrm{Rm} 8: 23$; 1 Cor 13:12).

\section{The illocutionary speech act}

Allowing the earnest, concerned intent of kingdom language to break through rather than impose authoritarianism: The intent of kingdom language, and the intensity with which it is spoken in biblical literature, might, at face value, seem to be intimidating and intrusive. A statement such as: 'For I tell you that unless your righteousness surpasses that of the Pharisees and the teachers of the law, you will certainly not enter the kingdom of heaven' (Mt 5:20), might, at first, sound intimidating and disheartening.

In an attempt to avoid the pitfalls of authoritarianism and manipulation, the intent of biblical kingdom language can be erroneously 'translated' into the current context in a way that softens its apparently abrasive nature (cf. Groothuis 2004:450). In this regard, Loscalzo (2000) writes the following:

Words like sin, judgement, immoral, evil, righteousness, faith and commitment have been purged from our progressive ecclesiastical vocabulary. We fear their use might rupture our hearers' boundaries and offend their sensibilities. We fear being stereotyped with both the religious right and the religious left. We have become so hyper cautious that our sermons at best offend no one and at worst merely bore. We fear being irrelevant, so our sermons become mundane chatter about raising self-actualized children or coping with the latest midlife crisis or providing five easy steps for managing anxiety.

(Loscalzo 2000:12)

The problem with the frame of mind that ultimately results from an overreaction to authoritarianism is that the earnest intent of kingdom language, which calls for a far-reaching response, may be neutralised. Dismissing the urge to embrace the radical newness of the kingdom may become only too easy, as Brueggemann (1989) argues:

The gospel is too readily heard and taken for granted, as though it contained no unsettling news and no unwelcome threat. What began as news in the gospel is easily assumed, slotted, and conveniently dismissed. We depart having heard, but without noticing the urge to transformation that is not readily compatible with our comfortable believing that asks little and receives less.

(Brueggemann 1989:1)

In order to attain a frame of mind that is sensitively tuned to the earnest intent of biblical kingdom language, sufficient faith-based perception needs to be gained with regard to the justifiability of God's imperatives in the context of the covenant. In no way should God's words be rendered unjustified either by placing improper pressure on the listener, by attempting to manipulate the listener against their will, or by trying to buy their allegiance. In the context of the covenantal relationship, the heavenly Father gives his all to restore a living relationship with his people through Jesus Christ and to enable them to willingly and joyfully reflect the goodness of their heavenly Father. He opens the eye that is blind. He renews the hardened heart. He lovingly heals the will that was shrivelled up in preoccupation with self-concern.

Listening in faith (with the new heart of a child of God) to kingdom language amounts to hearing the words of such language in a special way. Members of the kingdom community do not hear the voice of a tyrant who is set on manipulating them into submission or on ruling by fear. Instead, they hear the voice of a Father who is filled with earnest intent and concern for the well-being of his children, and who responds with a pressing urgency against all those factors that threaten to deplete the fullness of their communion with him. In such terms, surpassing the righteousness of the Pharisees is not a case of making the 
kingdom come into its own resources, but rather that of being urged to venture into the heretofore inconceivable spaces, which are opened up by the all-conquering majesty of God through Jesus Christ, to whom all authority in heaven, as well as on earth, belongs.

\section{The perlocutionary speech act}

Realising the consistent and authentic involvement (in the form of communion) that lies at the heart of the kingdom structure: Speech is experienced as inauthentic when the speaker lacks a sincere relationship with both the subject being discussed and the listeners being addressed. An endeavour to paint a vivid picture of a majestic mountain top, by means of the spoken word for listeners who have not yet been able to scale such heights, can only result in a rather unconvincing or one-dimensional account. Communication can only attain its full potential in the speech act of a speaker who finds himself in communion with the listener. They can then, in mutual awe, view the mountain towering into the sky before them. Trying to speak kingdom language without feeling the healing rays of the Sun of righteousness, who drives away the powers of darkness and death, will only result in words that are devoid of light and life. Such words are, inevitably, inauthentic, the listener concerned untouched, uninspired and unmoved.

By entering into living communion with God, the intensity of the covenantal relationship, which encompasses such emotions as love, righteousness, longsuffering, grace and justified anger, does not remain mere wording. The expression of such emotions does not leave the speaker and listener untouched, but is capable of filling both with the full, flaming intensity of God's presence. In speaking about the phenomenon of prophetic rage, as it is presented in the Bible, Brueggemann (1989:19) says that, although attempts have made to explain the extent of God's anger to us, we are still unaware of the full impact of such righteous ire. God's anger is conventionally reduced to the level of descriptions of mechanistic retributive principles of punishment, as though our wrongful acts automatically elicit punishment. What is missing from such a reductionist portrayal is that our God, who is both our progenitor and our hope, is the one who is affronted. Our lack of gratitude for the indescribably wonderful gifts that God gives to us calls forth prophetic rage, showing the hurt that our waywardness evokes in heaven Judgement that is not understood as a form of unendurable hurt misses the point of the biblical drama.

At the heart of the covenantal relationship with his people lies the reality that God remains faithful to his people. The covenantal relationship proves to be authentic in that at no stage does God become detached from his Word. At no stage does the disillusionment caused by people's breaking of his Word, or the despondency caused by faltering love, enter the relationship, as can happen in inter-human relationships. The act of speaking the words of the kingdom of God remains incomplete until the qualities of truthfulness and faithfulness are fully lived out in the lives and conduct of believers. Therefore, in Chan's (2007) words we can come to realise the following fundamental truth:

The verbalization of the truth of Christ is most powerful and effective when it is accompanied by the visualization of the gospel in the sense of seeing its salvific effects embodied in the lives of Christians.

(Chan 2007:314)

\section{CONCLUSION}

To speak the biblical language of the kingdom of God in all its flaming, covenantal intensity in the current context of a South African society in transition is no easy task. A speaker with a one-dimensional outlook on the religion that he or she practises might either be inclined to radicalise the kingdom language or, at the opposite extreme, to domesticate such language. Doing so might, in turn, lead the listener to interpret the language as manipulative, on the one hand, or as harmless and dismissible, on the other. In the absence of a communicable awareness of the love and righteousness of God as it is enacted in kingdom speech, the language of the kingdom of God may begin to sound like a noisy cymbal, which emits a clanging sound.

In the quest for developing a sensitivity to all the dimensions present in kingdom language, an initial investigation was conducted into the possibilities of speech act theory for working with the multiple facets of the language acts relating to the kingdom of God. Insight into the locutionary, illocutionary and perlocutionary dimensions of speech acts had to be gained in order to embark on a course set on obtaining a comprehensive and perspective-rich understanding of the length, breadth and depth of kingdom language. The essence of a language act in the context of the kingdom of God had to be described with respect to the way in which such an act establishes an awareness of the living presence of the King. In the language acts of God, the words that he uses cannot be divorced from him as an all-mighty being; such words also do not return empty to him.

Those who - by means of the work of the Spirit - have received eyes to sense the presence of God in his kingdom words and ears to listen to what the Spirit says to them, speak and listen from an enlightened vantage point. Such a vantage point enables them to reflect amazement at the brilliant clarity and overwhelming truth of kingdom language. It also enables them to appreciate both the earnest intent of a Father who is deeply concerned with his kingdom people and the authenticity of a communion that is bound - due to the covenantal presence of God - never to degenerate into less than that which has been promised.

\section{REFERENCES}

Allen, R.J., 2001, 'Preaching and postmodernism', Interpretation 55(1), 34-48

Austin, J.L., 1962, How to do things with words, Oxford University Press, Oxford.

Boeve, L., 2004, 'The shortest definition of religion: Interruption', Communio Viatorum 46(3), 299-322.

Botha, E., 2007, 'Speech act theory and biblical interpretation', Neotestamentica 41(2), 274-294.

Briggs, R.S., 2001, Words in action: Speech act theory and biblical interpretation, T\&T Clark, Edinburgh.

Bright, J., 1962, The kingdom of God, Abingdon Press, New York.

Brueggemann, W., 1989, Finally comes the poet: Daring speech for proclamation, Fortress, Minneapolis.

Brueggemann, W., 1997, Cadences of home: Preaching among exiles, John Knox Press, Louisville.

Bunting, H., 2005, 'Covenants, special relationships and a perfectly loving God', in J.A. Grant \& A.I. Wilson (eds.), The God of the covenant: Biblical, theological and contemporary perspectives, pp. 200-220, Apollos, Leicester.

Burns, L., 2009, The nearness of God: His presence with his people, P\&R Publishing, Phillipsburg.

Chan, M.L.Y., 2007, 'Following Jesus as the truth: Postmodernity and challenges of relativism', Evangelical Review of Theology 31(4), 306-319.

Dingemans, G.D.J., 1991, Als hoorder onder de hoorders. Een hermeneutische homiletiek [As a listener in the audience. A hermeneutical homiletics], Kok, Kampen.

Dörge, F.C., 2004, Illocutionary acts: Austin's account and what Searle made out of it, Eberhard-Karls-Universität, Tübingen.

Dumbrell, W.J., 1984, Covenant and creation: An Old Testament covenantal theology, Paternoster Press, Exeter.

Groothuis, D., 2004, 'Why truth matters most: An apologetic for truth-seeking in postmodern times', Journal of the Evangelical Theological Society 47(3), 441-454.

Hafemann, S.J., 2007. 'The covenant relationship', in S.J. Hafemann \& P.R. House (eds.), Central themes in biblical theology: Mapping unity in diversity, pp. 20-65, Baker Academic, Grand Rapids. 
Hendriks, A.N., 1991, Met het oog op de gemeente [With the eye on the congregation], Van den Berg, Kampen.

Huat Tan, K., 2005, 'Community, kingdom and cross: Jesus' view of covenant', in J.A. Grant \& A.I. Wilson (eds.), The God of Covenant: Biblical, theological and contemporary perspectives, pp. 122-155, Apollos, Leicester.

Johnston, G., 2001, Preaching to a postmodern world: A guide to reaching twenty-first century listeners, Baker, Grand Rapids.

Loscalzo, C.A., 2000, Apologetic preaching: Proclaiming Christ to a postmodern world, InterVarsity, Downers Grove.

Mann, S.T., 2009, 'You're fired: An application of speech act theory to 2 Samuel 15:23-16:14', Journal for the Study of the Old Testament 33(3), 315-334.

McComiskey, T.E., 1985, The Covenants of promise: A theology of the Old Testament covenants, Baker, Grand Rapids.

Muller, B.A., 1996, 'Profetiese prediking op pad na 2000 plus [Prophetic preaching on the road to 2000 and beyond]', in M. Nel (ed.), Prediking: Kommunikasie in konteks, pp. 47-78, Makro Boeke, Pretoria.

Nouwen, H.J.M., 1972, The wounded healer: Ministry in contemporary society, Image Books Doubleday, New York.
Pieterse, H.J.C. 2005, 'Die rol van Godskennis in die ontmoetingsgebeure met God in die prediking [The role of knowledge concerning God in the events of encountering God during preaching]', In die Skriflig 39(3), 409-422.

Root, M., 2007, 'Faith and order in a postmodern world: A response', Journal of Ecumenical Studies 42(4), 560-570.

Rottenberg, I.C., 1980, The promise and the presence: Towards a theology of the kingdom of God, Eerdmans, Grand Rapids.

Searle, J.R., 1969, Speech acts: An essay in the philosophy of language, Cambridge University Press, Cambridge.

Vanhoozer, K.J., 1998, Is there a meaning in this text? The Bible, the reader and the morality of literary knowledge, Apollos, Leicester.

Vorster, J.M., 2007, Christian attitude in the South African liberal democracy, Potchefstroom Theological Publications, Potchefstroom.

Vos, C.J.A., 1996, 'Die taallaser - 'n Homiletiese perspektief [The language laser - A Homiletic perspective]', in M. Nel (ed.), Prediking: Kommunikasie in konteks, pp. 27-46, Makro Boeke, Pretoria.

Wolterstorff, N., 1995, Divine discourse: Philosophical reflections on the claim that God speaks, Cambridge University Press, Cambridge. 